\title{
Vertical transport of lipid in seawater
}

\author{
Agneta Andersson ${ }^{1}$, Eva Selstam ${ }^{2}$, Åke Hagström ${ }^{1}$ \\ ${ }^{1}$ Dept of Microbiology and ${ }^{2}$ Dept of Plant Physiology, University of Umeă, S-901 87 Umeå, Sweden
}

\begin{abstract}
Lipids in seawater act as solvents and transporters of lipophilic organic pollutants. To investigate a possible transport route of lipophilic pollutants, the vertical flux of lipid was quantified during an annual cycle in the northern Baltic Sea. The lipid content in both sedimenting material and different size fractions of seawater was analyzed. During the year, $8 \mathrm{~g}$ lipid $\mathrm{m}^{-2}$ sedimented out from the photic zone to the benthic system. The sedimentation of lipid accounted for 300 to $400 \%$ of the average standing stock of pelagic lipid and was concentrated in the spring bloom period (April-June) when $70 \%$ of the total lipid sedimentation occurred. About $30 \%$ of the produced pelagic lipid settled out from the system. In seawater the lipid maximum occurred at the end of the spring bloom, shortly after nutrient depletion, indicating a stress response in the algae. Since lipid sedimentation is concentrated in the spring bloom, removal of lipophilic organic pollutants may be important during this period.
\end{abstract}

\section{INTRODUCTION}

Microorganisms constitute the major biomass and biosurface in seawater (e.g. Cho \& Azam 1990). Due to their lipophilic characteristics they form an initial target for organic pollutants in marine environments. Through biomagnification the toxic compounds may end up in higher trophic levels. (e.g. Taylor et al. 1991). Moreover, pollutants are transported vertically from the pelagic system to the benthic system by sedimentation. Naturally occurring lipids in plankton therefore act as solvents and transporters for organic pollutants (Parrish 1988).

Lipid is a component of both particulate organic material (POM) and dissolved organic material (DOM) in seawater. The lipid is composed of a variety of different classes; storage forms, membrane forms, partly degraded lipids and furthermore it includes various pollutants (Parrish 1988). The lipid content of plankton varies with the physiological state of the organisms. In response to stress, such as nutrient depletion or aging, algae increase their lipid concentration (Aaronson \& Bensky 1967, Roessler 1988). Under such situations, lipid formation occurs both by conversion of organic molecules such as proteins to lipids and by 'new' primary production (Roessler 1988). Lipids are energy-rich substances which can potentially be used as a food source for lipolytic micro- organisms, e.g. some marine seawater bacteria (Bruni et al. 1982). On the other hand, free fatty acids have an inhibitory effect on the growth of other organisms (Parrish 1988).

In a study by Taylor et al. (1991), the amount of pollutants as shown to be negatively correlated with plankton biomass, possibly as an effect of biomass dilution. These authors determined the concentrations of contaminating organochlorines in plankton biomass in 33 relatively closely situated lakes of different nutritional status. However, aquatic systems with high plankton biomass also have high sedimentation rates, and thus the pollutants in eutrophicated lakes may have been transported to the benthic system to a higher degree than in more oligotrophic lakes. Since hydrophobic organic pollutants absorb/adsorb preferentially to lipophilic compounds (Broman et al. 1991), it is of interest to know the amount and sedimentation rate of lipid in seawater. The present study focuses therefore on the association between pelagic lipid and sedimenting lipid.

We have used a data set, initially intended as a systems ecology budget analysis of a polluted coastal sea area, to quantify the vertical flux of lipid in seawater. The lipid content in sedimenting material and different size fractions of seawater was quantified during an annual cycle. Previous quantitative studies of lipids in seawater are limited and many studies 
cover only bloom events and not an entire annual cycle (e.g. Kattner et al. 1983a, b, Parrish et al. 1988). In this study plankton biomass was measured in order to find the relationship between lipid and plankton in different size fractions. Nutrients were measured as a potential cause of physiological stress of autotrophic organisms. The study was conducted in a temperate coastal sea area characterized by brackish water, a relatively short productive season, distinct plankton fluctuations and a varying river runoff.

\section{MATERIALS AND METHODS}

Study area. Seawater was collected from a sampling point situated in a transitory deposition basin in the Norrby archipelago $\left(63^{\circ} 31^{\prime} \mathrm{N}, 19^{\circ} 50^{\prime} \mathrm{E}\right)$ in the northern Baltic Sea. The archipelago is $10 \mathrm{~km}$ wide, has a salinity of 3 to $7 \%$ and is ca 20 to $30 \mathrm{~m}$ deep. Samples were taken in the photic zone $(0$ to $14 \mathrm{~m}) 15$ times during 1982. During the winter, the coastal sea area was permanently covered with ice from December to the beginning of May. The mean water temperature ranged from minimum $0^{\circ} \mathrm{C}$ during winter to maximum $15^{\circ} \mathrm{C}$ in August.

Cell counts and biomass determinations. Seawater from different depths was collected with a Ruttner sampler and pooled in an Ehrlenmeyer flask. Subsamples $(100 \mathrm{ml})$ were fixed with Lugol's solution $(0.2 \mathrm{ml})$ and 5 to $25 \mathrm{ml}$ settled overnight in a sedimentation chamber. Both pigmented and nonpigmented plankton were identified and quantified in an inverted microscope using $200 \times$ magnification. For each sample, half a chamber $\left(265 \mathrm{~mm}^{2}\right)$ was scanned. The size of different plankton ( $>50$ cells per taxonomic group) was measured using an ocular micrometer. The biomass of eukaryotic plankton was calculated from the plasma volume according to cell geometry, and by using the conversion factors $0.13 \mathrm{pg} \mathrm{C} \mathrm{m} \mathrm{m}^{-3}$ for armoured dinoflagellates and $0.11 \mathrm{pg} \mathrm{C} \mu^{-3}$ for other plankton (Edler 1979).

The total amount of bacteria (autotrophic and heterotrophic) was analyzed by staining seawater samples with ethidium bromide $\left(0.03 \mathrm{mg} \mathrm{ml}^{-1}\right)$ and quantifying the bacteria in an epifluorescence microscope, using $980 \times$ magnification and green excitation light (Zeiss filter set 487709). Four replicate slides were analyzed for each sample. About 300 cells slide ${ }^{-1}$ and at least 10 fields were counted. Bacterial biomass was calculated by measuring the size of the bacteria on microphotographs (>50 cells sample ${ }^{-1}$ ). The mean volume varied between 0.1 and $0.18 \mu^{-3}$. For calculation of bacterial biomass carbon, we used the conversion factor $20 \mathrm{fg}$ bacteria $^{-1}$, since it has been shown to be valid for a range of different sizes of bacteria (Lee \& Fuhrman 1987).
Nutrient analysis. Water samples from different depths were collected and analyzed for $\mathrm{NO}_{3}$ and $\mathrm{PO}_{4}$ using standard methods (Strickland \& Parsons 1972).

Sedimentation. Sedimentation from the photic layer (0 to $14 \mathrm{~m}$ ) was collected with a sediment trap (described in Blomqvist \& Håkanson 1981), containing 16 open glass tubes (height $120 \mathrm{~mm}$, diameter $25 \mathrm{~mm}$ ). Chloroform $(0.5 \mathrm{ml})$ was added to each tube to reduce biological activity. Sedimented material was collected every 2 to $3 \mathrm{wk}$, centrifuged, pooled and finally dried at $60^{\circ} \mathrm{C}$. Carbon content in sedimented material was analyzed using an elemental analyzer (Carlo Erba Model 1106).

Lipid extraction and quantification. A 51 seawater sample was collected with a Ruttner sampler from 0.5 , $2,4,6,8,10,12$ and $14 \mathrm{~m}$ depth and pooled in a polyethylene carboy. Before lipid extraction all labware was cleaned and rinsed with ethanol $(95 \%)$. Chloroform, methanol and isopropanol were redistilled. Cyclohexane was of analytical grade (Merck). Lipid in the free and particulate fractions was extracted as follows:

Free lipid: Cyclohexane was used for the extraction of free lipid since it left the plankton cells almost intact (chloroform was not used because it caused plankton disintegration). The pooled seawater sample was divided into 5 portions of 21 each, which were extracted twice with $100 \mathrm{ml}$ of cyclohexane. The quantity of lipid was 9 to 10 times higher in the first extraction than in the second.

Particulate lipid: Seawater (17 to 34 l) was consecutively filtered $(<2 \mathrm{~atm})$ onto 10 and $1 \mu \mathrm{m}$ polycarbonate filters (Uni-Pore polycarbonate, BIO-RAD $\varnothing 142 \mathrm{~mm}$ ), using a stainless steel Millipore air pressure unit. The weight of particles on the dried filters was determined. Lipid in filtered particles was extracted with isopropanol:water $4: 1(\mathrm{v} / \mathrm{v})$ by boiling $\left(76^{\circ} \mathrm{C}\right)$ and then sonicating the filters in an ultrasonic bath for $20 \mathrm{~min}$. Filters were removed and the lipid was extracted from the isopropanol:water extract, by adding chloroform and a water solution $(0.73 \% \mathrm{NaCl})$ to form a 'Bligh \& Dyer (1959) phase partition'. The fractionation efficiency of different plankton was checked by microscopy before and after filtration. Filtration did not cause severe cell disruption. To obtain the bacterial fraction, $15 \mathrm{l}$ of $1 \mu \mathrm{m}$ filtered seawater was centrifuged in a continuous-flow centrifuge (Sorvall KSB-R,

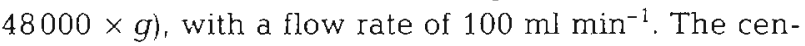
trifugation efficiency was ca $70 \%$ (SE $= \pm 4 \%$ ), determined by direct counts of bacteria before and after centrifugation. The centrifugation pellet was an unfixed mass of particles including the bacteria. The lipid in the samples was extracted as above. Lipid in sedimenting material was first dissolved by heating the samples to $80^{\circ} \mathrm{C}$ for $4 \mathrm{~h}$ in methanol: water $4: 1(\mathrm{v} / \mathrm{v})$ and $\mathrm{N}_{2}$ atmosphere. Then chloroform and water 
$(0.73 \% \mathrm{NaCl})$ were added and lipids were extracted according to Bligh \& Dyer (1959). The carbon content of lipid in the sedimenting material was analyzed using an elemental analyzer (Carlo Erba Model 1106)

Quantifying of lipid: To minimize nonlipid impurities, the extracts were reextracted once. The lipid extracts were dried on aluminium discs under a stream of nitrogen. Lipid was quantified gravimetrically using a Cahn 25 automatic electronic balance. Blank extractions were made with clean filters, distilled water and identical solvent systems. For cyclohexane extractions, the blank value was $19 \mu \mathrm{g}^{-1}$. In the particulate fractions $>10,1$ to 10 and 0.2 to $1 \mu \mathrm{m}$, it was 5,3 and $15 \mu \mathrm{g} \mathrm{l}^{-1}$, respectively. In the sediment samples, the blank extractions were between 7 and $16 \%$ in samples from February and March and between 0.3 and $1.5 \%$ in samples from May to October.

The lipid extracts were separated by thin layer chromatography (TLC). The retention times of the major lipid substances in seawater corresponded to hydrocarbons, sterol/ wax esters, triglycerides, free fatty acids, free sterols/alchohols, diglycerides and phospho-/glyco-lipids (data not shown). These results confirmed that the extracted lipids were of biological origin and that the samples were not contaminated.

Carbon analysis. Integrated seawater samples in the photic zone were collected as described above and analyzed for total organic carbon (TOC). Prior to analysis, the seawater samples were acidified with $\mathrm{HCl}$ and bubbled with $\mathrm{CO}_{2}$-free air to remove inorganic carbon. TOC was analyzed using a total organic carbon analyzer (Beckman Model 915B).

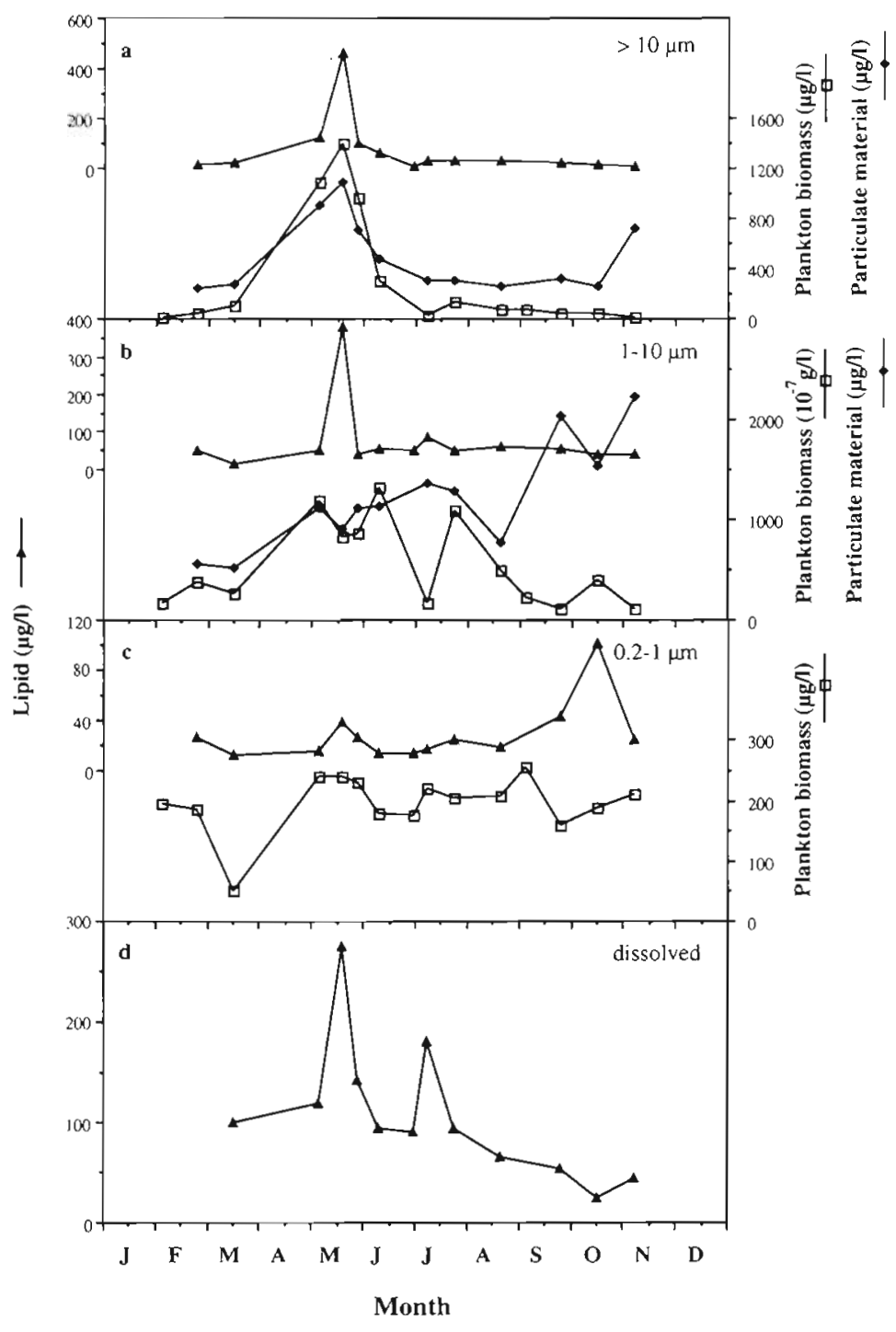

Fig. 1. Seasonal variation of pelagic lipid, plankton biomass (calculated from plasma volume) and particulate material in the photic zone (0 to $14 \mathrm{~m}$ ) in a coastal area in the northern Baltic Sea. Seawater was fractionated into

(a) $>10 \mu \mathrm{m}$, (b) 1 to $10 \mu \mathrm{m}$, (c) 0.2 to $1 \mu \mathrm{m}$ and (d) the dissolved fraction

\section{RESULTS}

\section{Plankton biomass and lipid in the pelagic system}

The total plankton biomass was relatively low (200 to $300 \mathrm{~g} \mathrm{I}^{-1}$ j during late autumn and winter, and consisted mainly of heterotrophic 0.2 to $1 \mu \mathrm{m}$ bacterioplankton (Fig. 1). The spring bloom peak in May was dominated by diatoms and dinoflagellates $(>10 \mu \mathrm{m}$, ca $\left.1400 \mu \mathrm{g} \mathrm{l}^{-1}\right)$. In this size fraction green algae and ciliates were also present in significant numbers later during the summer. After the spring bloom, plankton biomass decreased to 300 to $400 \mu \mathrm{g} \mathrm{l}^{-1}$ and was dominated by heterotrophic and autotrophic bacteria. The maximum of the 1 to $10 \mu \mathrm{m}$ fraction occurred during spring and summer, but it never dominated the plankton biomass. In this fraction, nanoflagellates and partly the same taxonomic groups as in the $>10 \mu \mathrm{m}$ fraction occurred. Because of the smaller cell sizes and the elongated or ameboid shapes during summer, some of them passed through the $10 \mu \mathrm{m}$ filter.

The lowest concentration of lipid was found during the ice period in February and March, and the highest concentration during the spring bloom (Fig. 1): the amount of particulate lipid (sum of fractions) increased from about $70 \mu \mathrm{gl}^{-1}$ in winter to a peak of $880 \mu \mathrm{gl}^{-1}$ in May at the spring bloom maximum. After the spring bloom particulate lipid was in the range of 100 to 


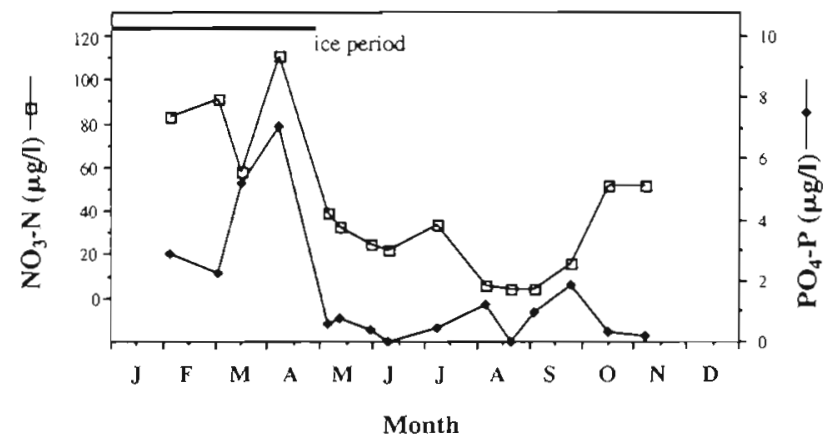

Fig. 2. Seasonal variation of nitrate and phosphate

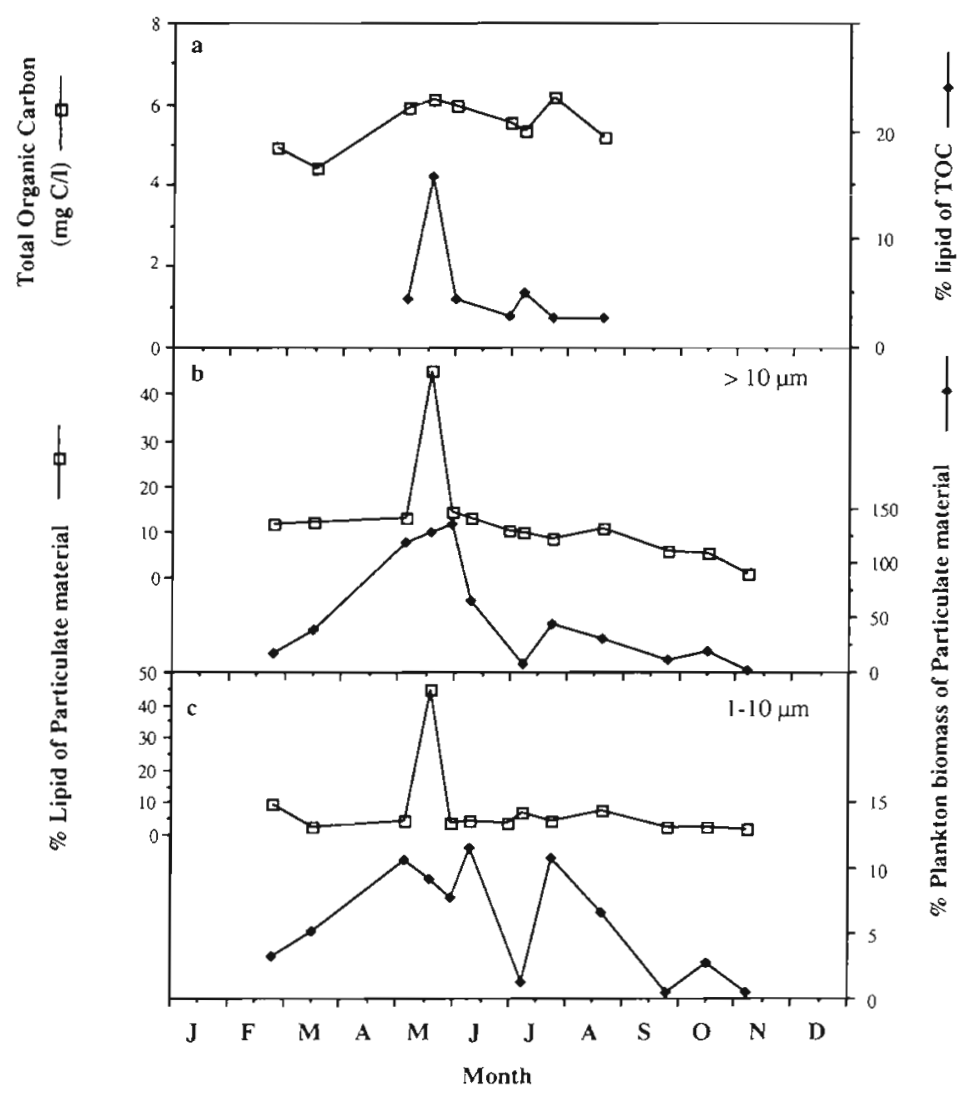

Fig. 3. (a) Total organic carbon (TOC) and percent lipid therein. Proportion of lipid and plankton biomass in particulate material in the size fractions (b) $>10 \mu \mathrm{m}$ and (c) 1 to $10 \mu \mathrm{m}$
$200 \mathrm{Mg} \mathrm{l}^{-1}$. The average lipid content over the year of the $>10$ and 1 to $10 \mu \mathrm{m}$ fractions was 46 and $58 \mu \mathrm{g} \mathrm{l}^{-1}$ respectively (Table 1$)$. In the bacterial fraction $(0.2$ to $1 \mu \mathrm{m})$, the amount of lipid was only about half that in the larger size fractions. The dissolved lipid was about one-third of total seawater lipid.

The lipid maximum at the end of spring bloom occurred shortly after the decrease in nutrients (Fig. 2), which indicated a stress response in the phytoplankton. The proportion of lipid in filtered particulate material and in TOC increased accordingly during this period (Fig. 3). At this time, lipid carbon constituted ca $70 \%$ of the plankton biomass in the $>10 \mu \mathrm{m}$ fraction. During other seasons how ever, lipid carbon often exceeded calculated plankton carbon (Table 1). Thus, lipid in the particulate fractions probably originated from both plankton and detritus.

Since the ratio of plankton biomass to filtered particulate material was lower in the 1 to $10 \mu \mathrm{m}$ fraction than in the $>10 \mu \mathrm{m}$ fraction, the proportion of detritus-derived lipid may have been higher in the smaller size fractions than in the $>10 \mu \mathrm{m}$ fraction (Fig. 3). Also, a significant positive correlation was obtained between the amount of lipid and the plankton biomass in the $>10 \mu \mathrm{m}$ size fraction ( $\mathrm{r}=0.85, \mathrm{p}<0.001$ ), while no significant correlations were found between these parameters in the 1 to $10 \mu \mathrm{m}$ and 0.2 to $1 \mu \mathrm{m}$ fractions. Plankton biomass constituted a variable fraction of the filtered particulate material (Fig. 3). In winter, the relative amount of plankton was only a few percent of the filtered particulate material. At the spring bloom maximum however, plankton biomass constituted most of the particulate material in the $>10 \mu \mathrm{m}$ fraction $(\mathrm{r}=0.88, \mathrm{p}<0.001)$. In the 1 to $10 \mu \mathrm{m}$ fraction there was no significant correlation between plankton biomass and filtered particulate material and the relative proportion of plankton biomass stayed low throughout the year, reaching at most $10 \%$ of the filtered particulate material.

Table 1. Annual average values for lipid, particulate material (PM) and calculated plankton biomass (PB) in different seawater fractions. Average ratios also given for lipid/PM, lipid/PB and lipid carbon (C)/plankton carbon (PC)

\begin{tabular}{|lcccccc|}
\hline Fraction & $\begin{array}{c}\text { Lipid } \\
\left(\mu \mathrm{g} \mathrm{I}^{-1}\right)\end{array}$ & $\begin{array}{c}\mathrm{PM} \\
\left(\mu \mathrm{g} \mathrm{l}^{-1}\right)\end{array}$ & $\begin{array}{c}\mathrm{PB} \\
\left(\mu \mathrm{g} \mathrm{l}^{-1}\right)\end{array}$ & Lipid/PM & Lipid/PB & Lipid C/PC \\
\hline$>10 \mu \mathrm{m}$ & 46 & 421 & 224 & 0.11 & 0.20 & 1.5 \\
$1-10 \mu \mathrm{m}$ & 58 & 1123 & 48 & 0.05 & 1.21 & 7.9 \\
$0.2-1 \mu \mathrm{m}$ & 28 & - & 188 & - & - & - \\
Dissolved & 77 & - & - & - & - \\
\hline
\end{tabular}




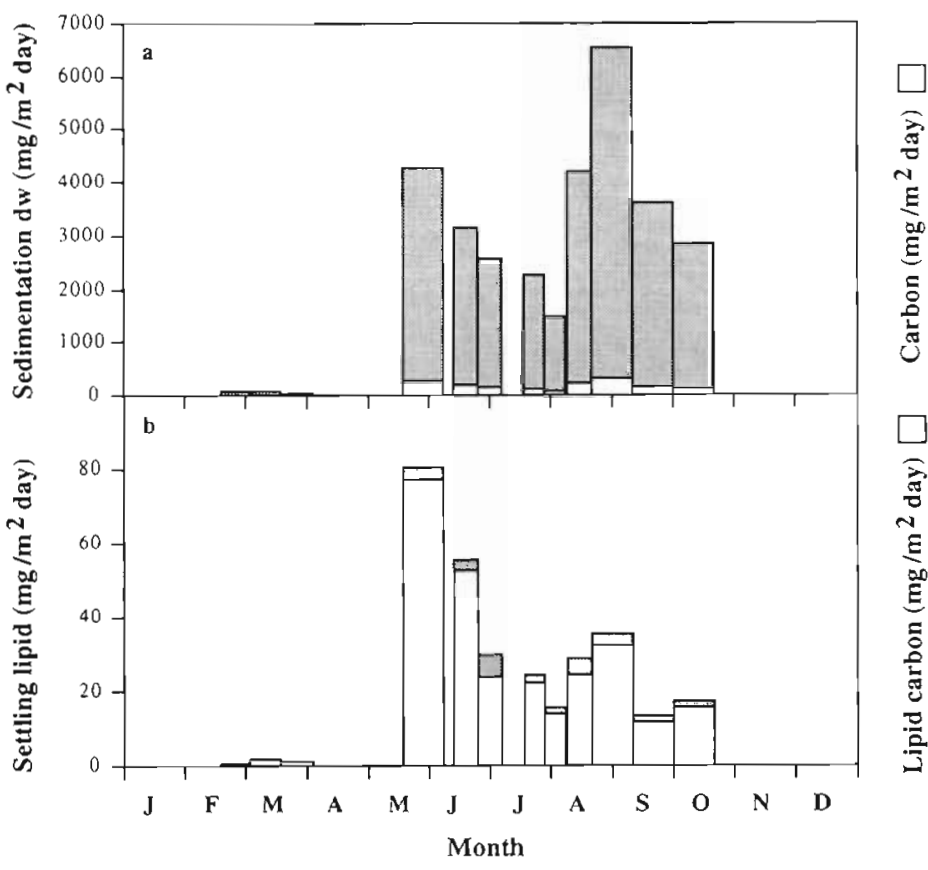

Fig. 4. Seasonal variation of sedimenting material, (a) Dry weight and total carbon content of sedimenting material and (b) lipid weight and lipid carbon content of sedimenting material

\section{Lipid in sedimentation}

There were peaks in sedimenting material both at the spring bloom and in the autumn (Fig, 4). Total sedimentation was $38 \mathrm{~g} \mathrm{C} \mathrm{m}^{-2} \mathrm{yr}^{-1}$ or $731 \mathrm{~g}^{\mathrm{dry}} \mathrm{wt} \mathrm{m}^{-2} \mathrm{yr}^{-1}$. Thus, the proportion of carbon was ca $5 \%$. Similar to the variation of lipid in the pelagic system, a lipid peak was also found in sedimenting material at the spring bloom maximum. The carbon content of lipid extracted from sedimenting material was ca $84 \%$, while nitrogen content was low, ca $1 \%$ (Table 2). The lipid nitrogen most likely originated from chlorophyll (the samples were green) and phospholipids (presence of polar lipids). During the year about $8 \mathrm{~g} \mathrm{~m}^{-2}$ lipid, mostly free

Table 2. Carbon and nitrogen content in lipid extracted from sedimentation samples

\begin{tabular}{|lcc|}
\cline { 2 - 3 } Month & $\begin{array}{c}\text { Lipid carbon } \\
(\%)\end{array}$ & $\begin{array}{c}\text { Lipid nitrogen } \\
(\%)\end{array}$ \\
\hline May & 89.6 & 1.0 \\
Jun & 89.2 & 0.8 \\
Jul & 73.7 & 1.4 \\
Jul & 85.8 & 1.8 \\
Aug & 86.3 & 1.3 \\
Aug & 80.2 & 1.3 \\
Sep & 85.2 & 1.4 \\
Mean & $84.3(\mathrm{SD}=5.6)$ & $1.3(\mathrm{SD}=0.3)$ \\
\hline
\end{tabular}

fatty acids (identified by TLC and gas chromatography, data not shown), sedimented out from the pelagic system.

\section{DISCUSSION}

This study was focused on the association between pelagic lipid and sedimenting lipid, which constitutes a potential transport route for organic pollutants. During the year, $8 \mathrm{~g}$ lipid $\mathrm{m}^{-2}$ sedimented out from the pelagic to the benthic system. This sedimentation of lipid corresponded to 300 to $400 \%$ of the average standing stock of pelagic lipid, i.e. the lipid in the photic layer was removed 3 to 4 times during the annual cycle. Moreover, lipid sedimentation was concentrated in the spring bloom period (April-June), when as much as $70 \%$ of the entire lipid sedimentation occurred.

The proportion of produced lipid that sedimented out from the pelagic system was calculated using the sum of the increase of pelagic and sedimenting lipid during the spring bloom period. During this period lipid production was ca $17 \mathrm{~g} \mathrm{~m}^{-2}$, while ca $5 \mathrm{~g} \mathrm{~m}^{-2}$ sedimented. Assuming that lipid sedimentation is a constant proportion of lipid production, at least $30 \%$ of the produced lipid sedimented out to the benthic system during 1 yr.

Since larger particles settle at higher rates than smaller ones, it may be assumed that particles $>10 \mu \mathrm{m}$ are dominant in the sedimenting matter. A covariation between lipid in particles $>10 \mu \mathrm{m}$ and lipid in sedimenting material was also observed $\left(\mathrm{r}^{2}=0.65\right.$, $p<0.05$ ). Thus, this fraction may be responsible for the vertical transport of absorbed/adsorbed organic pollutants in seawater. Dissolved lipid, adhered to particles, can of course also serve as transporter of lipophilic pollutants. In this study, the dissolved lipid fraction accounted for as much as $1 / 3$ of the total lipid content in the seawater.

Previous studies have reported similar variations of dissolved and particulate lipid depending on the type of water, time of year and water depth (Kennicutt \& Jeffrey 1981a, b, Kattner et al. 1983a, b, Parrish 1987. Parrish et al. 1988). In Table 3 the amounts of lipid found in the different dissolved and particulate fractions in our study, are compared to the results from other sea areas (Kennicutt \& Jeffrey 1981a, b, Kattner et al. 1983a, b, Parrish 1987, Parrish et al. 1988). For comparison, the dissolved and $<1 \mu \mathrm{m}$ fractions in our study were added, since the 'dissolved' lipid in the North Sea, Atlantic and Gulf of Mexico studies were 
Table 3. Comparison of quantities of dissolved and particulate total lipids $\left(\mu \mathrm{g}^{-1}\right)$ in different sea areas. Method of determination in parentheses - GW: gravimetric weight; DD: densitometric determination; FD: flame ionization detection. Part.: particulate; diss.: dissolved; - - not measured

\begin{tabular}{|c|c|c|c|c|c|c|c|c|c|c|}
\hline \multirow[t]{2}{*}{ Time } & \multicolumn{2}{|c|}{$\begin{array}{l}\text { Northern Baltic Sea }{ }^{a} \\
\qquad(G W)\end{array}$} & \multicolumn{2}{|c|}{$\begin{array}{l}\text { Fladen Ground, } \\
\text { North Sea }{ }^{\mathrm{b}} \\
\text { (DD) }\end{array}$} & \multicolumn{2}{|c|}{$\begin{array}{l}\text { Bedford Basin, } \\
\text { Atlantic west coast } \\
\text { (FD) }\end{array}$} & \multicolumn{2}{|c|}{$\begin{array}{c}\text { Scotian shelf, } \\
\text { Atlantic west coast } \\
\text { (FD) }\end{array}$} & \multicolumn{2}{|c|}{$\begin{array}{c}\text { Gulf of Mexico }{ }^{e} \\
\text { (GW) }\end{array}$} \\
\hline & $\begin{array}{l}0.2-1 \mu \mathrm{m} \\
+ \text { diss }\end{array}$ & $\begin{array}{l}\text { Part. } \\
>1 \mu \mathrm{m}\end{array}$ & $\begin{array}{l}\text { Diss. } \\
<1 \mu \mathrm{m}\end{array}$ & $\begin{array}{l}\text { Part. } \\
>1 \mu \mathrm{m}\end{array}$ & $\begin{array}{l}\text { Diss. } \\
<1 \mu \mathrm{m}\end{array}$ & $\begin{array}{l}\text { Part. } \\
>1 \mu \mathrm{m}\end{array}$ & $\begin{array}{l}\text { Diss. } \\
<1 \mu \mathrm{m}\end{array}$ & $\begin{array}{l}\text { Part. } \\
>1 \mu \mathrm{m}\end{array}$ & $\begin{array}{l}\text { Diss. } \\
<1 \mu \mathrm{m}\end{array}$ & $\begin{array}{l}\text { Part. } \\
>1 \mu \mathrm{m}\end{array}$ \\
\hline $\begin{array}{l}\text { Pre-/non- } \\
\text { bloom }\end{array}$ & $\sim 130$ & $35-66$ & 18 & $40-70$ & $150-300$ & $33-116$ & $49-190$ & $28-58$ & $60-160$ & $12-70$ \\
\hline $\begin{array}{l}\text { Bloom and } \\
\text { lipid max. }\end{array}$ & $130-290$ & $175-840$ & 25 & $70-156$ & 75 & $75-260$ & - & - & - & - \\
\hline Postbloom & $110-200$ & $115-75$ & 18 & $55-40$ & 498 & 240 & - & - & - & - \\
\hline \multicolumn{11}{|c|}{ 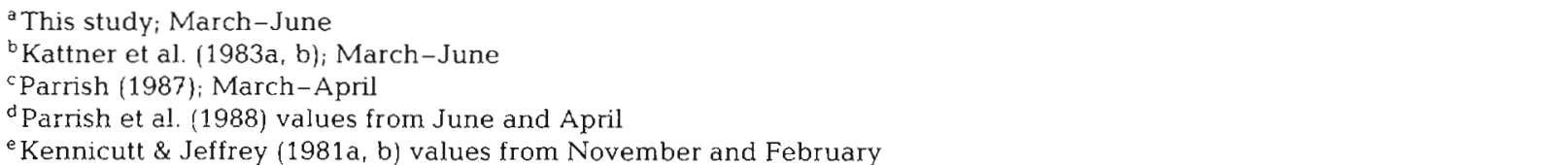 } \\
\hline
\end{tabular}

extracted after filtration through ca $1 \mu \mathrm{m}$ filters. Table 3 shows that the lipid content found in dissolved and particulate samples fluctuates in the same range before, during and after the spring bloom in the Baltic Sea, Fladen Ground and Bedford Basin.

In this study, the mean annual carbon content of lipid exceeded the calculated carbon content in plankton biomass in the 2 largest size fractions. This might be an effect of a high lipid content in the detritus material. There is also a possibility that the calculated plankton carbon was underestimated, since the physiological state of the plankton is not considered when using constant volume-to-carbon factors. To evaluate the results, the calculated carbon content in 2 different algal groups, was compared with chemically measured carbon content in exponentially growing cultures (Chan 1980): for similar sized cells of Thalassiosira spp. and Gymnodinium spp. we obtained 1620 and 56 pg C cell $^{-1}$, respectively, while Chan (1980) obtained 1750 and $55 \mathrm{pg} \mathrm{C}$ cell $^{-1}$ respectively. Therefore, we believe that our calculated mean carbon content is valid and that some of the extracted lipid originated from nonliving organic material.

The proportion of lipid in filtered particulate material ( 5 to $45 \%$ ) which was observed in this study agrees with previously published data: in algae cultures lipid content varies between 2 to $60 \%$ of dry weight, depending on the species composition and the physiological state of the algae (Parsons et al. 1961. Whyte 1987, Embadi \& Berland 1989, Parrish \& Wangersky 1990). Embadi \& Berland (1989) reported that the lipid content in Nannochloropsis salina and Pavlova lutheri decreased from 60 to $20 \%$ during the lag phase of growth, while exponential growth in lipid content gradually increased from 20 to $30 \%$. At the stationary phase lipid content was 30 to $60 \%$ of dry weight. It was found to be greater in small algae such as $N$. salina than in larger algae (Embadi \& Berland 1989). Growth limitation, e.g. caused by nitrogen stress, results in increased relative content of triglycerides in algae (Kattner et al. 1983a, Parrish \& Wangersky 1987, 1990). We also observed high amounts of lipid at the late spring bloom, probably due to the depletion of nitrogen and phosphorus which occurred in late April.

The TOC in the coastal area of the northern Baltic Sea was approximately $5 \mathrm{mg} \mathrm{C}{ }^{-1}$. This is about 2 to 3 times more than in Atlantic seawater (Gordon \& Sutcliffe 1973, Sharp 1973). The higher TOC concentration in the Baltic Sea may be a consequence of high input of allochtonous material to this area. POC was measured not in this study, but in the same sea area during 1991 by Andersson \& Rudehäll (1993). The POC values show that the relative lipid carbon content in particles $>1 \mu \mathrm{m}$ would be ca $20 \%$. This is in accordance with the lipid carbon content of sedimenting material, composing about $18 \%$ of the TOC. Our results are comparable to those found at Fladen Ground (Kattner et al. 1983a, b), referring to the proportion of total fatty acids of DOM (3\%) and POM $(30 \%)$. In the Gulf of Mexico, the lipid content of DOC and POC was 4 and $20 \%$ respectively (Kennicutt \& Jeffrey $1981 \mathrm{a}, \mathrm{b}$ ) and in the Kiel Bight a lipid content of ca $25 \%$ of POC was found by Smetacek \& Hendrikson (1979).

In summary, about $8 \mathrm{~g}$ lipid $\mathrm{m}^{-2}$ sedimented out from the photic layer during the year. Lipid sedimentation 
accounted for 300 to $400 \%$ of the average standing stock of pelagic lipid, and was concentrated in the spring bloom period (April-June) when $70 \%$ of total lipid sedimentation occurred. In conclusion, we suggest that removal of lipophilic pollutants from the pelagic system to the benthic system should be important mainly during the spring bloom. The lipid-rich sedimenting material during the spring bloom is then incorporated into benthic organisms (Hill et al. 1992). During other seasons, when the vertical transport of lipid is relatively low, toxic compounds may be accumulated in the pelagic food web.

Acknowledgements. This work was supported by grants from the Swedish Environmental Protection Agency and the Swedish Natural Science Research Council. We thank Mrs Eva-Lena Hornfeldt for technical assistance. The laboratory facilities of the Umeå Marine Sciences Center are gratefully acknowledged.

\section{LITERATURE CITED}

Aaronson, S., Bensky, B. (1967). Effect of aging of a cell population in lipids and drug resistance in Ochromonas danica. J. Protozool. 14: 76-78

Andersson, A., Rudehäll, $\AA$. (1993). Proportion of plankton biomass in particulate organic carbon in the northern Baltic Sea. Mar. Ecol. Prog. Ser. 95: 133-139

Bligh, E. E., Dyer, W. J. (1959). A rapid method of total lipid extraction and purification. Can. J Biochem. Physiol. 37 911-917

Blomqvist, S., Håkanson, L. (1981). A review on sediment traps in aquatic systems. Arch. Hydrobiol. 91: 101-132

Broman, D., Näf, C., Rolff, C., Zebühr, Y. (1991). Occurrence and dynamics of polychlorinated dibenzo-p-dioxins and dibenzofurans and polycyclic aromatic hydrocarbons in the mixed surface layer of remote coastal and offshore waters of the Baltic. Environ. Sci. Technol. 25: $1850-1864$

Bruni, V., Maugeri, T., Alonzo, V. (1982). Lipolytic activity of marine bacteria. Influence of $\mathrm{NaCl}$ and $\mathrm{MgCl}_{2}$. Mar. Biol. 67: $113-119$

Chan, A. T. (1980). Comparative physiological study of marine diatoms and dinoflagellates in relation to irradiance and cell size. II. Relationship between photosynthesis, growth and carbon/chlorophyll a ratio. J. Phycol. 16: $428-432$

Cho, B., Azam, F. (1990). Biogeochemical significance of bacterial biomass in the ocean's euphotic zone. Mar. Ecol. Prog. Ser. 63: 253-259

Edler, L. (1979). Recommendations on methods for marine biological studies in the Baltic Sea. The Baltic Marine Biologists (BMB) Publ. No. 5. Gotab, Malmö

Embadi, D., Berland, B. (1989). Variation in lipid class composition during batch growth of Nannochloropsis salina and Pavlova lutheri. Mar. Chem. 26: 215-225

Gordon, D. C. Jr, Sutcliffe, W. H. Jr (1973). A new dry combustion method for the simultaneous determination of total organic carbon and nitrogen in seawater. Mar. Chem. 1: $231-244$

Hill, C., Quigley, M. A., Cavaletto, J. F., Gordon, W. (1992). Seasonal changes in lipid content and composition in the benthic amphipods Monoporeia affinis and Pontoporeia femorata. Limnol. Oceanogr. 37: 1280-1289

Kattner, G., Gercken, G., Eberlein, K. (1983a). Development of lipids during a spring plankton bloom in the northern North Sea. I. Particulate fatty acids. Mar. Chem. 14 $149-162$

Kattner, G., Gercken, G., Hammer, K. D. (1983b). Development of lipids during a spring plankton bloom in the northern North Sea. II. Dissolved lipids and fatty acids. Mar. Chem. 14: 163-173

Kennicutt, M. C. II, Jeffrey, L. M. (1981a). Chemical and GC-MS characterization of marine dissolved lipids. Mar. Chem. 10: 364-387

Kennicutt M. C. II, Jeffrey, L. M. (1981b). Chemical and GC-MS characterization of marine particulate lipids. Mar. Chem. 10: 389-407

Lee, S., Fuhrman, J. A. (1987). Relationships between biovolume and biomass of naturally derived marine bacterioplankton. Appl. environ. Microbiol. 53: 1298-1303

Parrish, C. C. (1987). Time series of particulate and dissolved lipid classes during spring phytoplankton blooms in Bedford Basin, a marine inlet. Mar. Ecol. Prog. Ser. 35: $129-139$

Parrish, C. C. (1988). Dissolved and particulate marine lipid classes: a review. Mar. Chem. 23: 17-40

Parrish, C. C., Wangersky, P. J. (1987). Particulate and dissolved lipid classes in cultures of Phaeodactylum tricornatum grown in cage culture turbidostates with a range of nitrogen supply rates. Mar. Ecol. Prog. Ser. 35: 119-128

Parrish, C. C., Wangersky, P. J. (1990). Growth and lipid class composition of the marine diatom Chaetoceros gracilis, in laboratory and mass culture turbidostats. J. Plankton Res. 12: $1011-1021$

Parrish, C. C., Wangersky, P. J., Delmas, R. P., Ackman, R. G. (1988). latroscan-measured profiles of dissolved and particulate marine lipid classes over the Scotian slope and Bedford basin. Mar. Chem. 23: 1-15

Parsons, T. R., Stephens, K., Strickland, J. D. H. (1961). On the chemical composition of eleven species of marine phytoplankters. J. Fish. Res. Bd Can. 18: 1001-1016

Roessler, P. G. (1988). Effects of silicon deficiency on lipid composition and metabolism in the diatom Cyclotella cryptica. J. Phycol. 24: 394-400

Sharp, J. H. (1973). Total organic carbon in seawater comparison of measurements using persulfate oxidation and high temperature combustion. Mar. Chem. 1: 211-229

Smetacek, V., Hendrikson, P. 1979. Composition of particulate organic matter in Kiel Bight in relation to phytoplankton succession. Oceanol. Acta 2: 287-298

Strickland, J. D. H., Parsons, T. R. (1972). A practical handbook of seawater analysis. Fisheries Research Board of Canada, Ottawa

Taylor, W. D., Carey, J. H., Lean, D. R. S., McQueen, D. J. (1991). Organochlorine concentrations in the plankton of lakes in southern Ontario and their relationship to plankton biomass. Can. J. Fish. Aquat. Sci. 48: 1960-1966

Whyte, J. N. C. (1987). Biochemical composition and energy content of six species of phytoplankton used in mariculture of bivalves. Aquaculture 60: 231-241

Manuscript first received: November 6, 1992

Revised version accepted: June 1, 1993 